\title{
Data report: X-ray florescence scanning of sediment cores, Site U1419, Gulf of Alaska'
}

\author{
Michelle Penkrot, ${ }^{2}$ Leah J. LeVay, ${ }^{3}$ and John M. Jaeger ${ }^{2}$
}

\section{Chapter contents}

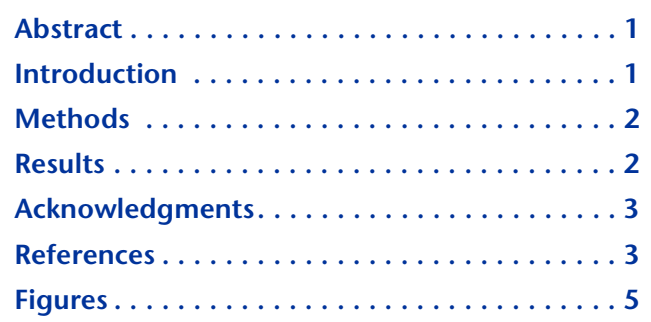

'Penkrot, M., LeVay, L.J., and Jaeger, J.M., 2017. Data report: X-ray florescence scanning of sediment cores, Site U1419, Gulf of Alaska. In Jaeger, J.M., Gulick, S.P.S., LeVay, L.J., and the Expedition 341 Scientists, Proceedings of the Integrated Ocean Drilling Program, 341: College Station, TX (Integrated Ocean Drilling Program). doi:10.2204/iodp.proc.341.203.2017

${ }^{2}$ Department of Geological Sciences, University of Florida, Gainesville FL 32611, USA.

Correspondence author: mpenkrot@ufl.edu ${ }^{3}$ International Ocean Discovery Program, Texas A\&M University, College Station TX 77845, USA.

\section{Abstract}

Semiquantitative elemental results from X-ray fluorescence (XRF) scanning of sediment cores from Integrated Ocean Drilling Program (IODP) Site U1419 in the Gulf of Alaska are presented. This site contains varying lithofacies that have been previously correlated with glacial-interglacial changes in sedimentation and water-column productivity. XRF scanning was conducted to aid in interpretation of sedimentation during the last glacial period.

Crossplots of elements often interpreted as detrital and biogenically sourced show positive correlations between $\mathrm{Ca}$ and $\mathrm{Al}, \mathrm{Si}, \mathrm{Ti}$, $\mathrm{Sr}$, and $\mathrm{Si}$ with $\mathrm{Al}$, with no correlation between $\mathrm{Ca}$ and $\mathrm{Ba}$. When detrital elements were compared with volume-corrected shipboard magnetic susceptibility (MS), Fe and Ti appear to positively covary, whereas $\mathrm{Al}$ inversely covaries. $\mathrm{K}$ shows a similar downhole pattern to $\mathrm{Fe}$ and $\mathrm{Ti}$, whereas $\mathrm{Si}$ is similar to $\mathrm{Al}$. $\mathrm{Zr}$ alternates between positively and negatively covarying with $\mathrm{Fe}, \mathrm{Ti}$, and $\mathrm{K}$. Mn, $\mathrm{Rh}, \mathrm{Rb}$, and $\mathrm{Pb}$ intensities show patterns similar to $\mathrm{K}, \mathrm{Ti}$, and $\mathrm{Fe}$, whereas $\mathrm{Sr}$ is similar to $\mathrm{Ca}$ and $\mathrm{Cr}$ is similar to $\mathrm{Al}$ and $\mathrm{Si}$. $\mathrm{Ni}$ and $\mathrm{Zn}$ intensities are inversely related to $\mathrm{Al}, \mathrm{Si}$, and $\mathrm{Zr}$. $\mathrm{S}$ roughly mirrors trends displayed by $\mathrm{Ca}$. $\mathrm{Mo}, \mathrm{Nb}, \mathrm{Y}, \mathrm{Ga}, \mathrm{Ge}, \mathrm{P}, \mathrm{Ba}, \mathrm{Bi}, \mathrm{As}$, and $\mathrm{Cu}$ intensities show little to no downhole variation, and changes in $\mathrm{Br}$ and $\mathrm{Cl}$ intensities are most likely related to water content.

\section{Introduction}

Site U1419, drilled during Integrated Ocean Drilling Program (IODP) Expedition 341, is located on the upper continental slope in the northern Gulf of Alaska (Fig. F1) (see the "Site U1419" chapter [Jaeger et al., 2014b]). Previous results from the site reveal a high-resolution, heterolithic, deglacial-modern sedimentary record (Davies et al., 2011; Addison et al., 2012). The drilling objectives of Site U1419 were to extend this record of glacial dynamics and paleoceanography into the late Pleistocene. The primary objectives were to constrain the timing of modern to late Pleistocene glacial events of the northwestern Cordilleran ice sheet. The secondary objectives were to document the influence of North Pacific sea-surface temperatures as a control on the regional glacial dynamics and to address the dynamics of productivity and intermediate water circulation on hypoxia in the region.

Previous work done at this site revealed the link between the varied sedimentary lithofacies and the water column and glacima- 
rine processes. Diamicts accumulated from the deglacial $(\sim 17.5 \mathrm{ka})$ through to $\sim 14.8 \mathrm{ka}$, after which warming coincident with the Bølling Interstate of northern Europe and Greenland resulted in a lithofacies transition to laminated mud (Davies et al., 2011). Periods of enhanced water column productivity and bottom water hypoxia between 10.7 and 14.8 $\mathrm{ka}$ are recognized by this laminated facies (Addison et al., 2012). The Holocene period of accumulation consists of massive bioturbated mud (Davies et al., 2011).

The periodic correspondence of the Gulf of Alaska paleoclimate with events in the North Atlantic suggests that strata accumulating at Site U1419 prior to the deglacial could contain stadial and interstadial periods with varied productivity and glacigenic sedimentation (Praetorius and Mix, 2014). Lithofacies and sediment composition are expected to follow these potential changes. To create a high spatial resolution elemental data set to capture these changes, scanning X-ray fluorescence (XRF) analyses were performed on core sections within the stratigraphically continuous spliced composite record (see the "Site U1419" chapter [Jaeger et al., 2014b]). Elements of interest were those commonly used to identify changes in lithofacies and paleoproductivity (Rothwell and Croudace, 2015). In this report, we present the raw count data for all measured elements of interest. The data are available for all measured sections as CSV files in XRF in "Supplementary material." Downcore and box and whisker plots of all elements are provided in DOWNHOLE and BOXPLOTS in "Supplementary material."

\section{Methods}

Scanning XRF data were collected at the XRF core facility located at the International Ocean Discovery Program Gulf Coast Repository (GCR) at Texas A\&M University, using a third-generation Avaatech XRF core scanner. The core scanner is able to measure the surface of half-round core sections for elements between $\mathrm{Mg}$ and $\mathrm{U}$ on the periodic table (http:// www.avaatech.com). Only core sections located on the continuous Site U1419 splice were analyzed (see Table T10 in the "Site U1419" chapter [Jaeger et al., $2014 \mathrm{~b}]$ ), rather than every core section collected at the site. However, some off-splice sections located near questionable splice tie points (see Figs. F16B and F17B in the "Site U1419" chapter [Jaeger et al., 2014b]) were also analyzed in order to help refine the Site U1419 splice.

Prior to scanning, each core section was warmed up to room temperature, scraped to clean the core sur- face, and covered with $4 \mu \mathrm{m}$ thick Ultralene plastic film to prevent contamination of the measuring prism. Cores were warmed up before covering with the film to prevent condensation underneath the plastic, which can affect X-ray attenuation (Tjallingii et al., 2007).

XRF data were collected every $2 \mathrm{~cm}$, with sample locations occasionally being shifted to avoid protruding clasts, cracks, and depressions along the core surface. Two scans were completed for each core section at different voltages: 10 and $30 \mathrm{kV}$. The $10 \mathrm{kV}$ scan was for the elements $\mathrm{Al}, \mathrm{Si}, \mathrm{P}, \mathrm{Cl}, \mathrm{Ar}, \mathrm{K}, \mathrm{Ca}, \mathrm{Ti}, \mathrm{Cr}$, $\mathrm{Mn}, \mathrm{Fe}, \mathrm{Rh}$, and $\mathrm{Ba}$ and the $30 \mathrm{kV}$ scan was for $\mathrm{Fe}, \mathrm{Ni}$, $\mathrm{Cu}, \mathrm{Zn}, \mathrm{Ga}, \mathrm{Ge}, \mathrm{As}, \mathrm{Br}, \mathrm{Rb}, \mathrm{Sr}, \mathrm{Y}, \mathrm{Zr}, \mathrm{Nb}, \mathrm{Mo}, \mathrm{Pb}$, and Bi. Settings used for the $10 \mathrm{kV}$ scan were a tube current of $0.5 \mathrm{~mA}$ and detection time of $20 \mathrm{~s}$. For the 30 $\mathrm{kV}$ scan a tube current of $1 \mathrm{~mA}$ and a detection time of $30 \mathrm{~s}$ were used. The sample irradiation area was 10 $\mathrm{mm}$ in the downcore direction and $15 \mathrm{~mm}$ in the crosscore direction. All XRF data are presented as counts per second in XRF in "Supplementary material."

\section{Results}

The scanning XRF data in this report provide a highresolution record of the geochemistry at Site U1419. Crossplots of elements often associated with detrital and biogenic sources in marine sediments are shown in Figure F2 (Rothwell and Croudace, 2015). Weak positive covariance is seen for $\mathrm{Ca}$ and $\mathrm{Al}$ and for $\mathrm{Ca}$ and $\mathrm{Si}$, with the increased amount of scatter most likely due to increased effects of water content on the low atomic mass and weakly fluorescing $\mathrm{Al}$ and Si atoms (Tjallingii et al., 2007). Positive covariance is observed between $\mathrm{Ca}$ and $\mathrm{Ti}$, Ca and $\mathrm{Sr}$, and $\mathrm{Si}$ and Al. However, a slight negative relationship is observed at extremely high Ca counts between $\mathrm{Ca}$ and Ti. There appears to be no relationship between $\mathrm{Ca}$ and $\mathrm{Ba}$.

Downhole element distributions of $\mathrm{Al}, \mathrm{Ca}, \mathrm{Fe}, \mathrm{K}, \mathrm{Si}$, $\mathrm{Ti}$, and $\mathrm{Zr}$ are plotted along with volume-corrected magnetic susceptibility (MS) in Figure F3 (Walczak et al., 2015). All plots are on a core composite depth below seafloor (CCSF-B) depth scale in meters, which is the composite depth scale corrected for compaction (see the "Methods" chapter [Jaeger et al., 2014a]). When comparing detrital elements $\mathrm{Al}, \mathrm{Fe}$, and $\mathrm{Ti}$ with MS, Al appears to inversely covary, whereas $\mathrm{Ti}$ and Fe appear to positively covary. Si exhibits similar downhole variability to $\mathrm{Al}$, and $\mathrm{K}$ appears to covary with $\mathrm{Fe}$ and $\mathrm{Ti}$. Zr inversely covaries with $\mathrm{Ti}, \mathrm{Fe}$, and $\mathrm{K}$ shallower than $27 \mathrm{~m}$ CCSF-B and deeper than $65 \mathrm{~m}$ CCSF-B but positively covaries between 27 and $65 \mathrm{~m}$ 
CCSF-B. Ca displays the strongest downhole variability, with the degree of variation increasing downhole.

Downhole plots of measured elements not shown in Figure F3 along with box and whisker plots of all measured elements are available in DOWNHOLE and BOXPLOTS in "Supplementary material." Of these elements, $\mathrm{Mn}, \mathrm{Rh}, \mathrm{Rb}$, and $\mathrm{Pb}$ show patterns similar to $\mathrm{K}, \mathrm{Ti}$, and $\mathrm{Fe}$, whereas $\mathrm{Sr}$ is similar to $\mathrm{Ca}$, and $\mathrm{Cr}$ is similar to $\mathrm{Al}$ and $\mathrm{Si}$. Ni and $\mathrm{Zn}$ are inversely related to $\mathrm{Al}, \mathrm{Si}$, and $\mathrm{Zr}$. $\mathrm{S}$ roughly mirrors trends displayed by $\mathrm{Ca}$ and is characterized by a large peak at $36 \mathrm{~m}$ CCSF-B. Mo, Nb, Y, Ga, Ge, P, Ba, Bi, As, and $\mathrm{Cu}$ show little to no downhole variation. Mo, $\mathrm{Nb}, \mathrm{Y}, \mathrm{Ga}$, $\mathrm{As}$, and $\mathrm{Cu}$ have been previously measured in the Gulf of Alaska by inductively coupled plasma-mass spectrometry (ICP-MS) at concentrations of a few parts per million (Barron et al., 2009), which most likely falls below the detection limit of the XRF scanner at the GCR, and thus their downhole values likely represent noise. $\mathrm{Ba}$ and $\mathrm{P}$ have been measured via ICP-MS at concentrations higher than the AVAATECH XRF scanner detection limit (Richter et al., 2006). Bi and Ge are typically found in extremely low concentrations of $<2 \mathrm{ppm}$ in continental crust (Rudnick and Gao, 2003) and are assumed to be below the detection limit of the GCR XRF scanner. Changes in $\mathrm{Br}$ and $\mathrm{Cl}$ intensities are most likely related to water content (Tjallingii et al., 2007). Positive $\mathrm{Ar}$ values indicate measurements where X-rays were transmitted through air due core disturbance (i.e., cracks) or bubbles underneath the plastic film.

\section{Acknowledgments}

This research used samples and data provided by the Integrated Ocean Drilling Program (IODP). Funding for this research was provided by a Consortium for Ocean Leadership U.S. Scientist Support Program post Expedition Award to L.J. LeVay and J.M. Jaeger. We also thank Christian März for his thoughtful review and helpful suggestions.

\section{References}

Addison, J.A., Finney, B.P., Dean, W.E., Davies, M.H., Mix, A.C., Stoner, J.S., and Jaeger, J.M., 2012. Productivity and sedimentary $\delta^{15} \mathrm{~N}$ variability for the last 17,000 years along the northern Gulf of Alaska continental slope. Paleoceanography, 27(1):PA1206. https://doi.org/ 10.1029/2011PA002161

Barron, J.A., Bukry, D., Dean, W.E., Addison, J.A., and Finney, B., 2009. Paleoceanography of the Gulf of Alaska during the past 15,000 years: results from diatoms, sili- coflagellates, and geochemistry. Marine Micropaleontology, 72(3-4):176-195. http://dx.doi.org/10.1016/ j.marmicro.2009.04.006

Davies, M.H., Mix, A.C., Stoner, J.S., Addison, J.A., Jaeger, J., Finney, B., and Wiest, J., 2011. The deglacial transition on the southeastern Alaskan margin: meltwater input, sea level rise, marine productivity, and sedimentary anoxia. Paleoceanography, 26(2):PA2223. https:// doi.org/10.1029/2010PA002051

Jaeger, J.M., Gulick, S.P.S., LeVay, L.J., Asahi, H., Bahlburg, H., Belanger, C.L., Berbel, G.B.B., Childress, L.B., Cowan, E.A., Drab, L., Forwick, M., Fukumura, A., Ge, S., Gupta, S.M., Kioka, A., Konno, S., März, C.E., Matsuzaki, K.M., McClymont, E.L., Mix, A.C., Moy, C.M., Müller, J., Nakamura, A., Ojima, T., Ridgway, K.D., Rodrigues Ribeiro, F., Romero, O.E., Slagle, A.L., Stoner, J.S., St-Onge, G., Suto, I., Walczak, M.H., and Worthington, L.L., 2014a. Methods. In Jaeger, J.M., Gulick, S.P.S., LeVay, L.J., and the Expedition 341 Scientists, Proceedings of the Integrated Ocean Drilling Program, 341: College Station, TX (Integrated Ocean Drilling Program). https://doi.org/10.2204/iodp.proc.341.102.2014

Jaeger, J.M., Gulick, S.P.S., LeVay, L.J., Asahi, H., Bahlburg, H., Belanger, C.L., Berbel, G.B.B., Childress, L.B., Cowan, E.A., Drab, L., Forwick, M., Fukumura, A., Ge, S., Gupta, S.M., Kioka, A., Konno, S., März, C.E., Matsuzaki, K.M., McClymont, E.L., Mix, A.C., Moy, C.M., Müller, J., Nakamura, A., Ojima, T., Ridgway, K.D., Rodrigues Ribeiro, F., Romero, O.E., Slagle, A.L., Stoner, J.S., St-Onge, G., Suto, I., Walczak, M.H., and Worthington, L.L., 2014b. Site U1419. In Jaeger, J.M., Gulick, S.P.S., LeVay, L.J., and the Expedition 341 Scientists, Proceedings of the Integrated Ocean Drilling Program, 341: College Station, TX (Integrated Ocean Drilling Program). https://doi.org/10.2204/iodp.proc.341.105.2014

Praetorius, S.K., and Mix, A.C., 2014. Synchronization of North Pacific and Greenland climates preceded abrupt deglacial warming. Science, 345(6195):444-448. https:// doi.org/10.1126/science. 1252000

Richter, T.O., van der Gaast, S., Koster, B., Vaars, A., Gieles, R., de Stigter, H.C., De Haas, H., and van Weering, T.C.E., 2006. The Avaatech XRF Core Scanner: technical description and applications to NE Atlantic sediments. In Rothwell, R.G. (Ed.), New Techniques in Sediment Core Analysis. Geological Society Special Publication, 267(1):39-50. https://doi.org/10.1144/

GSL.SP.2006.267.01.03

Rothwell, R.G., and Croudace, I.W., 2015. Twenty years of XRF core scanning marine sediments: what do geochemical proxies tell us? In Croudace, I.W., and Rothwell, R.G. (Eds.), Micro-XRF Studies of Sediment Cores. Developments in Paleoenvironmental Research, 17:25102. https:/doi.org/10.1007/978-94-017-9849-5_2

Rudnick, R.L., and Gao, S., 2003. Composition of the continental crust. In Rudnick, R.L. (Ed.), Treatise on Geochemistry (Vol 3): The Crust. Holland, H.D., and Turekian, K.K. (Series Eds.): Oxford, UK (Elsevier), 1-64. https://doi.org/10.1016/B0-08-043751-6/03016-4 
Tjallingii, R., Röhl, U., Kölling, M., and Bickert, T., 2007. Influence of the water content on X-ray fluorescence core-scanning measurements in soft marine sediments. Geochemistry, Geophysics, Geosystems, 8(2):Q02004. https://doi.org/10.1029/2006GC001393

Walczak, M.H., Mix, A.C., Willse, T., Slagle, A., Stoner, J.S., Jaeger, J., Gulick, S., LeVay, L., Kioka, A., and the IODP Expedition 341 Scientific Party, 2015. Correction of non-intrusive drill core physical properties data for vari- ability in recovered sediment volume. Geophysical Journal International, 202(2):1317-1323. https://doi.org/ 10.1093/gji/ggv204

Initial receipt: 17 August 2016

Acceptance: 3 May 2017

Publication: 21 July 2017

MS 341-203 
Figure F1. The Gulf of Alaska region: geography and location of Expedition 341 sites. DSDP = Deep Sea Drilling Project, ODP = Ocean Drilling Program.

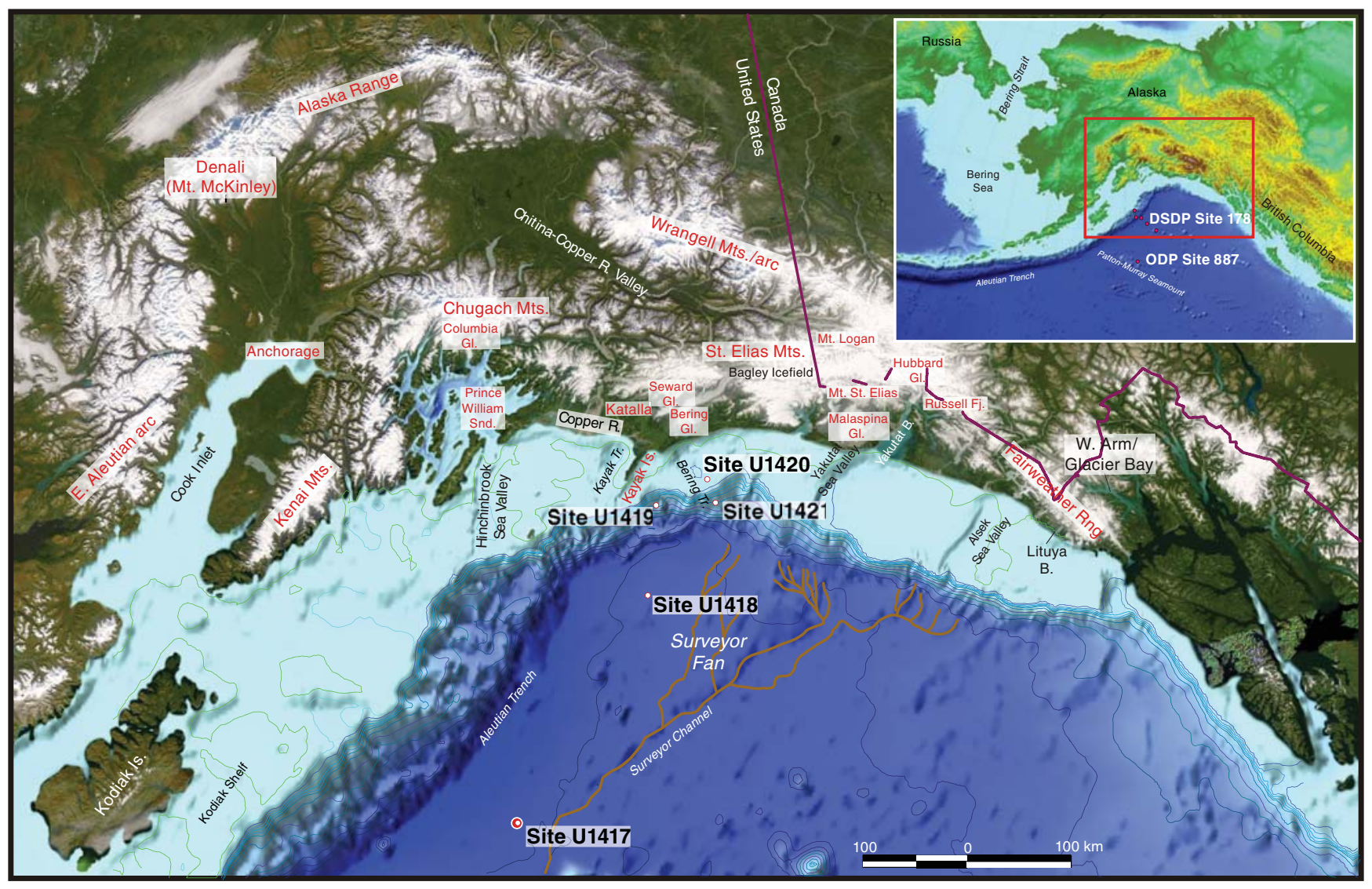


Figure F2. Crossplots of elements typically associated with detrital and biogenic inputs to marine sediments: Ca vs. Al, Ca vs. Si, Ca vs. Ti, Ca vs. Ba, Ca vs. Sr, and Si vs. Al.
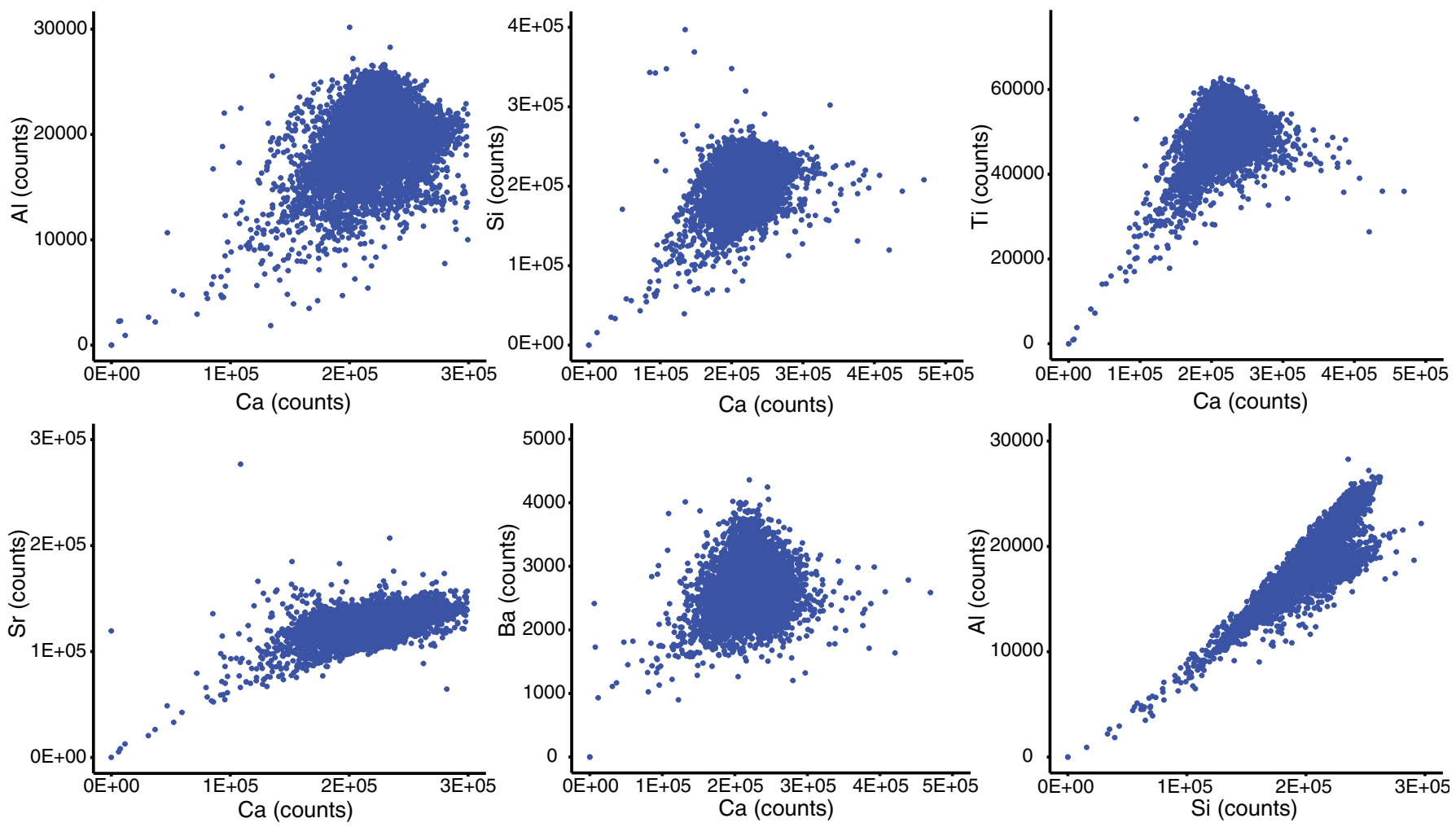
Figure F3. XRF scanner counts for $\mathrm{Al}, \mathrm{Ca}, \mathrm{K}, \mathrm{Fe}, \mathrm{Si}$, $\mathrm{Ti}$, and $\mathrm{Zr}$ with volume-corrected magnetic susceptibility (MS) (Walczak et al., 2015). Gray shaded band is assumed to represent glacimarine diamict to hypoxic laminated facies transition that is observed at $14.8 \mathrm{ka}$ in EW0408 85JC (Davies et al., 2011). Gray horizontal lines highlight points of major variations in MS as it relates to variability in detrital elements (i.e., $\mathrm{Al}, \mathrm{Fe}$, and Ti).

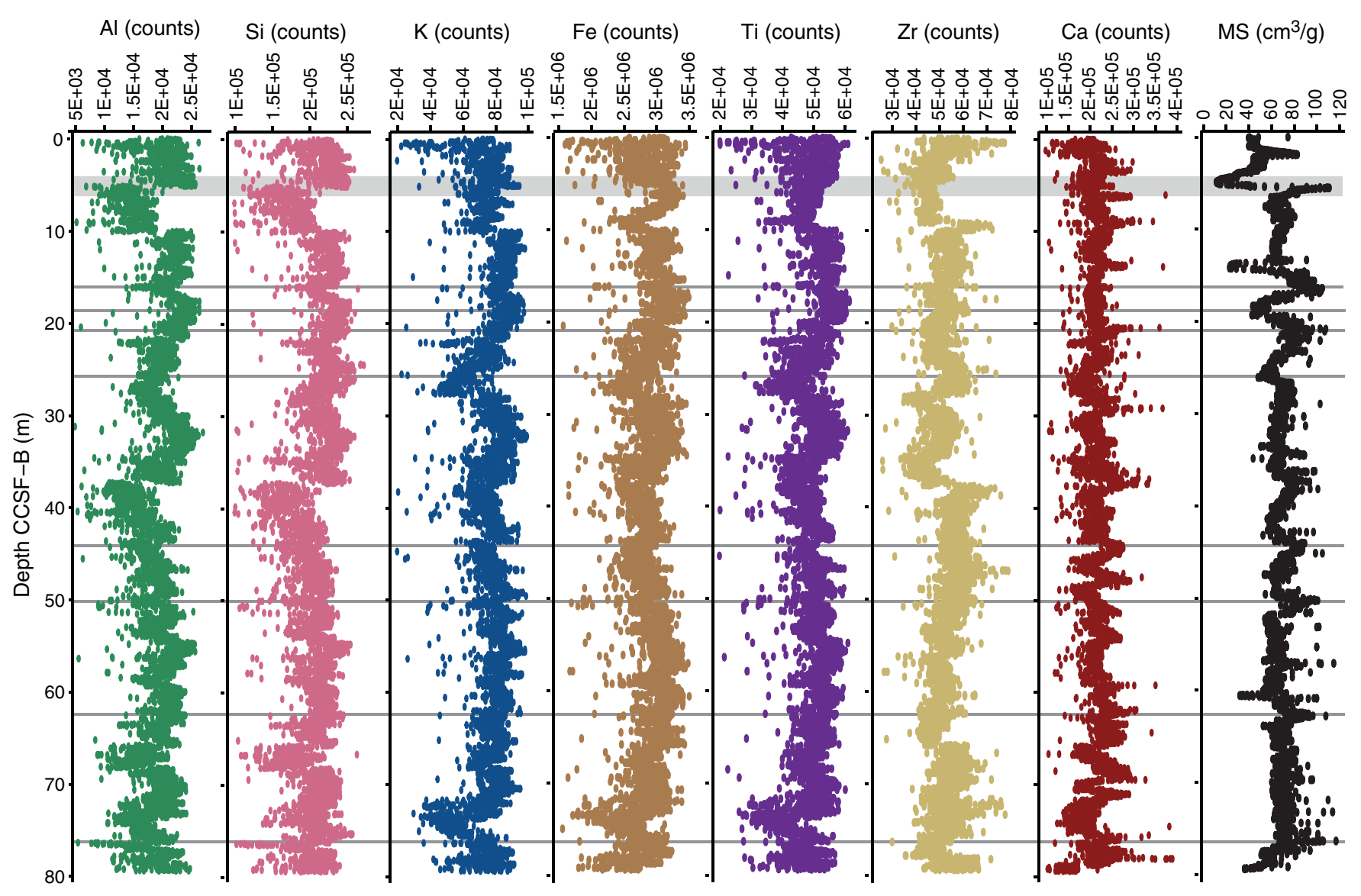

